\title{
PYRIDAZINE AND ITS RELATED COMPOUNDS, SYNTHESIS OF SOME NOVEL CONDENSED PYRIDAZINES
}

\author{
Ali Deeb ${ }^{1}$, Ahmed Hataba ${ }^{1}$, Wafaa I. El-Eraky ${ }^{2}$ and Hend Abdel-Naby ${ }^{1}$ \\ 1 -Department of Chemistry, Faculty of Science, Zagazig University, Zagazig, Egypt. \\ 2 - Department of Pharmacology, National Research Centre, Dokki, Cairo, Egypt
}

\begin{abstract}
A series of pyridazino[3,4-d][1,3] oxazin-5-one derivatives were designed and synthesized through a versatile method. Reaction of chloro-ester 1 with sodium azide has afforded azido-ester $\mathbf{2}$ which reacted with triphenylphosphine to produce compound $\mathbf{3}$; amino-ester $\mathbf{4}$ was formed upon treatment of compound $\mathbf{3}$ with acetic acid 80\%; this amino-ester $\mathbf{4}$ was then hydrolyzed to the amino-acid $\mathbf{5}$ which is considered the starting material. The approach involves treatment of pyridazinamino-acid $\mathbf{5}$ with acetic anhydride, benzoyl chloride, triethylorthoformate, ethyl chloroformate, diethyl oxalate, phthalic anhydride as well as succinic anhydride to yield pyridazino[3,4-d][1,3]oxazin-5-one derivatives $6,8,9,10,11,12$ and 13 . The new synthesized compounds were confirmed by their infrared, mass spectrum and ${ }^{1} \mathrm{H}-\mathrm{NMR}$.
\end{abstract}

Keywords: Pyridazine, 1,3-Oxazin-6-one, Pyridazino[3,4-d][1,3]oxazin-5-one, Synthesis, Condensation.

\section{Introduction}

Pyridazine and its fused heterocyclic derivatives have recently received much attention from their reactions, synthetic and effective biological importance [13]. It has been reported to possess antimicrobial [4], antituberculosis [5, 6], antifungal [7], anticancer [8], herbicidal [9] activities, and plant growth regulators and crop protecting agents [10].

In the light of these facts, our interest was focused on synthesizing new heterocyclic compounds including pyridazinoxazines moieties with suitable substituent of biological and pharmacological interest. The structures of the newly synthesized compounds were elucidated on the basis of various 
spectroscopic methods and in some cases by comparison with samples previously prepared by unambiguous route.

\section{Materials and methods}

All melting points were determined in open glass capillaries and are uncorrected. IR spectra were recorded on a BRUKER Vector 22 Germany spectrometer (KBr). ${ }^{1} \mathrm{H}-\mathrm{NMR}$ spectra were recorded on Varian Gemini $200 \mathrm{MHz}$ spectrometer, using tetramethylsilane (TMS) as an internal reference. The Electron Impact mass spectra were obtained at $70 \mathrm{eV}$ using Shimadzu QP-2010 Plus mass spectrometer. The reactions were followed up by thin layer chromatography (TLC) on silica gel $\mathrm{F}_{254}$ aluminum sheets (Merck), the spots were detected by UV lamp at 254-365 $\mathrm{nm}$.

\section{Synthesis of ethyl-3-azido-5,6-diphenylpyridazine-4- carboxylate (2)}

To a solution of compound 1 (3.385 g, $0.01 \mathrm{~mole})$ in ethanol $(20 \mathrm{ml})$ sodium azide ( $1.95 \mathrm{~g}, 0.03$ mole) was added. The reaction mixture was refluxed for $5 \mathrm{~h}$., the solvent was evaporated under reduced pressure until dryness, $200 \mathrm{ml}$ water was added then drops of conc $\mathrm{HCl}$. The precipitate was filtered off and washed with water. After dryness the product was recrystallized from ethanol. White crystals, yield 71.3\%, mp 118-120 ${ }^{\circ} \mathrm{C}$, IR $\left(\mathrm{KBr}, \mathrm{cm}^{-1}\right)$ : $1734(\mathrm{C}=\mathrm{O}), 2338\left(\mathrm{~N}_{3}\right)$, ${ }^{1} \mathrm{H}-\mathrm{NMR}\left(\mathrm{DMSO}-d_{6}\right): \delta=0.9\left(\mathrm{t}, 3 \mathrm{H}, \mathrm{CH}_{3}\right), 4.13-4.22\left(\mathrm{q}, 2 \mathrm{H}, \mathrm{CH}_{2}\right), 7.18-7.36$ (m, 10H, 2Ph).

\section{Synthesis of ethyl 5,6-diphenyl-3}

((triphenylphosphoranylidene)amino)pyridazine-4- carboxylate (3)

To a solution of compound 2 (3.45 $\mathrm{g}, 0.01 \mathrm{~mole})$ in benzene $(20 \mathrm{ml})$ triphenylphosphene $(5.24 \mathrm{~g}, 0.02$ mole) was added. The reaction mixture was refluxed for $8 \mathrm{~h}$., the solvent was evaporated under reduced pressure until dryness, and the residue was treated with excess amount of diethylether. The precipitate was filtered off and washed with diethyl ether. After dryness the product was recrystallized from ethanol. White crystals, yield 86.35\%, mp 178$180{ }^{\circ} \mathrm{C}, \mathrm{IR}\left(\mathrm{KBr}, \mathrm{cm}^{-1}\right): 1728(\mathrm{C}=\mathrm{O}),{ }^{1} \mathrm{H}-\mathrm{NMR}$ (DMSO-d $): \delta=0.92-1.08(\mathrm{t}, 3 \mathrm{H}$, $\left.\mathrm{CH}_{3}\right), 4.12-4.18$ (q, 2H, $\left.\mathrm{CH}_{2}\right), 7.11-7.86(\mathrm{~m}, 25 \mathrm{H}, 5 \mathrm{Ph})$.

\section{Synthesis of ethyl-3-amino-5,6-diphenylpyridazine-4- carboxylate( 4)}

A solution of compound 3 ( $1 \mathrm{~g}, 0.0017$ mole $)$ in glacial acetic acid $80 \%(10 \mathrm{ml})$ was refluxed for $8 \mathrm{~h}$., the reaction mixture was poured into ice water, drops of $\mathrm{NH} 4 \mathrm{OH}$ solution was added. The precipitate was filtered off and recrystallized from ethanol. White crystals, yield 82.98\%, mp 188-190 ${ }^{\circ} \mathrm{C}, \mathrm{IR}\left(\mathrm{KBr}, \mathrm{cm}^{-1}\right)$ : $1708(\mathrm{C}=\mathrm{O}), 3476,3272\left(\mathrm{NH}_{2}\right),{ }^{1} \mathrm{H}-\mathrm{NMR}\left(\mathrm{DMSO}-d_{6}\right): \delta=0.79-0.84(\mathrm{t}, 3 \mathrm{H}$, $\mathrm{CH}_{3}$ ), 3.94-4.01 (q, 2H, $\left.\mathrm{CH}_{2}\right), 7.04-7.29$ (m, 10H, 2Ph), 6.7 (s, 2H, $\mathrm{NH}_{2}$ ). 


\section{Synthesis of 3-amino-5,6-diphenylpyridazine-4-carboxylic acid (5)}

A solution of compound 4 ( $1 \mathrm{~g}, 0.003$ mole) in ethanolic sodium hydroxide $2 \mathrm{~N}$ $(10 \mathrm{ml})$ was refluxed for $5 \mathrm{~h}$., the solvent was evaporated under reduced pressure until dryness, and the residue was treated with water. On acidification with conc $\mathrm{HCl}$, a precipitate was obtained which was filtered off, washed several times with water and recrystallized from methanol. White crystals, yield $87.9 \%, \mathrm{mp}$ 233-235 ${ }^{\circ} \mathrm{C}$, IR $\left(\mathrm{KBr}, \mathrm{cm}^{-1}\right): 1658(\mathrm{C}=\mathrm{O}), 3352,3270\left(\mathrm{NH}_{2}\right),{ }^{1} \mathrm{H}-\mathrm{NMR}$ (DMSO$\left.d_{6}\right): \delta=7.18-7.36(\mathrm{~m}, 10 \mathrm{H}, 2 \mathrm{Ph}), 6.9\left(\mathrm{~s}, 2 \mathrm{H}, \mathrm{NH}_{2}\right)$.

Synthesis of 7-methyl-3,4-diphenyl-5H-pyridazino[3,4-d][1,3]oxazin-5-one (6)

Method A:

A solution of compound 5 ( $1 \mathrm{~g}, 0.0034$ mole) in acetic anhydride $(5 \mathrm{ml})$ was refluxed for $18 \mathrm{~h}$., the mixture was poured into water. The precipitate was filtered, dried and washed with diethyl ether. After dryness the product was recrystallized from ethanol. Brown crystals, yield $74 \%, \mathrm{mp} 280-282^{\circ} \mathrm{C}$, IR $(\mathrm{KBr}$, $\left.\mathrm{cm}^{-1}\right): 1695(\mathrm{C}=\mathrm{O}), 1556(\mathrm{C}=\mathrm{N}),{ }^{1} \mathrm{H}-\mathrm{NMR}\left(\mathrm{DMSO}-d_{6}\right): \delta=2.49-2.51(\mathrm{~s}, 3 \mathrm{H}$, $\left.\mathrm{CH}_{3}\right), 7.2-7.3(\mathrm{~m}, 10 \mathrm{H}, 2 \mathrm{Ph}) . \mathrm{MS} \mathrm{m} / z(\%): 316\left[\mathrm{M}^{+}+1\right](0.03), 274\left[\mathrm{M}^{+}-\mathrm{N}\right.$ $=\mathrm{CMe}]\left(2.57, \mathrm{~F}_{1}\right), 230\left[\mathrm{~F}_{1}-\mathrm{CO}_{2}\right]\left(0.54, \mathrm{~F}_{2}\right), 153\left[\mathrm{~F}_{2}-\mathrm{Ph}\right](0.92)$.

\section{Method B:}

To a solution of compound 30 (3.19 g, 0.01 mole) in acetic acid (15 ml) acetic anhydride $(24 \mathrm{ml})$ and sodium acetate $(2 \mathrm{~g})$ were added, the mixture was refluxed for $15 \mathrm{~h}$., then poured into water. The precipitate was filtered, dried and washed with diethyl ether $(2.44 \mathrm{~g}, 77.4 \%)$. After dryness the product was recrystallized from ethanol, it was identical with that prepared by method $\mathbf{A}$.

\section{Synthesis of 3-benzamido- 5,6-diphenylpyridazine-4- carboxylic acid (7)}

To a solution of compound 5 ( $0.3 \mathrm{~g}, 0.001$ mole $)$ in pyridine $(5 \mathrm{ml})$ benzoyl chloride $(0.28 \mathrm{~g}, 0.23 \mathrm{ml}, 0.002$ mole) was added drop by drop at room temperarure. The reaction mixture was stirred for additional $3 \mathrm{~h}$., and the solid product formed upon pouring into ice water containing few drops of conc $\mathrm{HCl}$ was collected by filteration, washed with excess amount of water, dried and recrystallized from methanol. White crystals, yield $75 \%, \mathrm{mp} 138-140{ }^{\circ} \mathrm{C}$, IR $\left(\mathrm{KBr}, \mathrm{cm}^{-1}\right): 1685(\mathrm{C}=\mathrm{O}), 3064(\mathrm{NH}), 3425(\mathrm{OH}){ }^{1} \mathrm{H}-\mathrm{NMR}\left(\mathrm{DMSO}-d_{6}\right): \delta=$ 7.15-8.06 (m, 15H, 3Ph), $11.4(\mathrm{~s}, 1 \mathrm{H}, \mathrm{NH}), 11.8$ (s, 1H, OH). MS m/z (\%): 395 $\left[\mathrm{M}^{+}\right](0.11), 250\left[\mathrm{M}^{+}-\mathrm{COOH}\right]\left(49.76, \mathrm{~F}_{1}\right), 230\left[\mathrm{~F}_{1}-\mathrm{HNCOPh}\right]\left(0.57, \mathrm{~F}_{2}\right), 153\left[\mathrm{~F}_{2}\right.$ $-\mathrm{Ph}](0.14)$.

Synthesis of 3,4,7-triphenyl-5H-pyridazino[3,4-d]-1,3-oxazin-5-one (8)

To a solution of compound $\mathbf{5}$ ( $0.3 \mathrm{~g}, 0.001$ mole $)$ in pyridine $(5 \mathrm{ml})$ benzoyl chloride ( $0.28 \mathrm{~g}, 0.23 \mathrm{ml}, 0.002$ mole ) was added drop by drop at room 
temperature. The reaction mixture was refluxed for $15 \mathrm{~h}$. After cooling the reaction mixture was poured into ice water containing few drops of conc $\mathrm{HCl}$ and the precipitate was filtered, dried and washed with ethanol. After dryness the product was recrystallized from methanol. White crystals, yield 64.4\%, mp 285$287{ }^{\circ} \mathrm{C}$, IR $\left(\mathrm{KBr}, \mathrm{cm}^{-1}\right): 1769(\mathrm{C}=\mathrm{O}), 1587(\mathrm{C}=\mathrm{N}),{ }^{1} \mathrm{H}-\mathrm{NMR}\left(\mathrm{DMSO}-d_{6}\right): \delta=$ 7.15-8.31 (m, 15H, 3Ph). MS m/z (\%): $377\left[\mathrm{M}^{+}\right](5.25), 274\left[\mathrm{M}^{+}-\mathrm{N}=\mathrm{CPh}\right]$ $\left(1.46, \mathrm{~F}_{1}\right), 230\left[\mathrm{~F}_{1}-\mathrm{CO}_{2}\right]\left(16.53, \mathrm{~F}_{2}\right), 153\left[\mathrm{~F}_{2}-\mathrm{Ph}\right](0.13)$.

\section{Synthesis of 3,4-diphenyl-5H-pyridazino[3,4-d]-1,3-oxazin-5-one (9)}

A solution of compound 5 ( $1 \mathrm{~g}, 0.0034$ mole $)$ in triethylorthoformate $(5 \mathrm{ml})$ was refluxed for $12 \mathrm{~h}$., the mixture was evaporated to dryness in air and the residue was treated with diethyl ether. The precipitate was filtered off, dried and recrystallized from benzene. Brown crystals, yield 67.6\%, mp 163-165 ${ }^{\circ} \mathrm{C}$, IR $\left(\mathrm{KBr}, \mathrm{cm}^{-1}\right): 1675(\mathrm{C}=\mathrm{O}), 1588(\mathrm{C}=\mathrm{N}), \mathrm{MS} \mathrm{m} / z(\%): 299\left[\mathrm{M}^{+}-2\right](0.07), 274$ $\left[\mathrm{M}^{+}-\mathrm{CH}=\mathrm{N}\right]\left(0.09, \mathrm{~F}_{1}\right), 230\left[\mathrm{~F}_{1}-\mathrm{CO}_{2}\right]\left(0.09, \mathrm{~F}_{2}\right), 153\left[\mathrm{~F}_{2}-\mathrm{Ph}\right](3.40)$.

Synthesis of 7-ethoxy-3,4-diphenyl-5H-pyridazino[3,4-d]-1,3-oxazin-5-one (10)

To a solution of compound 5 ( $1 \mathrm{~g}, 0.0034$ mole ) in pyridine ( $5 \mathrm{ml}$ ) ethyl chloroformate ( $0.37 \mathrm{~g}, 0.32 \mathrm{ml}, 0.0034$ mole ) was added drop by drop at room temperature. The reaction mixture was refluxed for $10 \mathrm{~h}$. After cooling the reaction mixture was poured into ice water containing few drops of conc $\mathrm{HCl}$ and the precipitate was filtered, dried and washed with water. After dryness the product was recrystallized from ethanol. Brown crystals, yield 76.2\%, mp 268$270{ }^{\circ} \mathrm{C}, \mathrm{IR}\left(\mathrm{KBr}, \mathrm{cm}^{-1}\right): 1695(\mathrm{C}=\mathrm{O}), 1556(\mathrm{C}=\mathrm{N}), \mathrm{MS} \mathrm{m} / \mathrm{z}(\%): 346\left[\mathrm{M}^{+}+1\right]$ $(0.61), 274\left[\mathrm{M}^{+}-\mathrm{N}=\mathrm{COEt}\right]\left(0.61, \mathrm{~F}_{1}\right), 230\left[\mathrm{~F}_{1}-\mathrm{CO}_{2}\right]\left(0.09, \mathrm{~F}_{2}\right), 153\left[\mathrm{~F}_{2}-\mathrm{Ph}\right]$ (6.40).

Synthesis of ethyl 5-oxo-3,4-diphenyl-5H-pyridazino[3,4-d]-1,3-oxazine-7carboxylate (11)

To a solution of compound 5 ( $1 \mathrm{~g}, 0.0034$ mole ) in dimethyl formamide ( $10 \mathrm{ml}$ ) diethyl oxalate $(0.41 \mathrm{~g}, 0.0034$ mole $)$ was added. The reaction mixture was refluxed for $12 \mathrm{~h}$. After cooling the reaction mixture was poured into ice water and the precipitate was filtered, dried and washed with water. After dryness the product was recrystallized from ethanol. White crystals, yield 70.3\%, mp 140$142{ }^{\circ} \mathrm{C}$, IR $\left(\mathrm{KBr}, \mathrm{cm}^{-1}\right): 1627(\mathrm{C}=\mathrm{O}$ cyclic $), 1663(\mathrm{C}=\mathrm{O}$ ester $), 1595(\mathrm{C}=\mathrm{N})$, $\mathrm{MS} m / z(\%): 373\left[\mathrm{M}^{+}\right](0.01), 300\left[\mathrm{M}^{+}-\mathrm{COOEt}\right]\left(0.11, \mathrm{~F}_{1}\right), 256\left[\mathrm{~F}_{1}-\mathrm{CO}_{2}\right](0.05$, $\left.\mathrm{F}_{2}\right), 179\left[\mathrm{~F}_{2}-\mathrm{Ph}\right](3.40)$.

Synthesis of 2-( 5-oxo-3,4-diphenyl-5H-pyridazino[3,4-d]-1,3-oxazin-7yl)benzoic acid (12) 
To a solution of compound 5 ( $1 \mathrm{~g}, 0.0034$ mole ) in dimethyl formamide ( $10 \mathrm{ml}$ ) phthalic anhydride ( $0.5 \mathrm{~g}, 0.0034$ mole ) was added. The reaction mixture was refluxed for $9 \mathrm{~h}$. After cooling the reaction mixture was poured into ice water and the precipitate was filtered, dried and washed with water. After dryness the product was recrystallized from ethanol. White crystals, yield 76.3\%, mp 238$240{ }^{\circ} \mathrm{C}, \mathrm{IR}\left(\mathrm{KBr}, \mathrm{cm}^{-1}\right): 3433(\mathrm{OH}), 1725(\mathrm{C}=\mathrm{O}$ cyclic $), 1784(\mathrm{C}=\mathrm{O}$ acid $), 1578$ $(\mathrm{C}=\mathrm{N}), \mathrm{MS} \mathrm{m} / \mathrm{z}(\%): 421\left[\mathrm{M}^{+}\right](0.03), 300\left[\mathrm{M}^{+}-\mathrm{C} 6 \mathrm{H} 4-\mathrm{COOH}\right]\left(0.28, \mathrm{~F}_{1}\right), 256$ $\left[\mathrm{F}_{1}-\mathrm{CO}_{2}\right]\left(2.68, \mathrm{~F}_{2}\right), 179\left[\mathrm{~F}_{2}-\mathrm{Ph}\right](6.03)$.

\section{Synthesis of 3-( 5-oxo-3,4-diphenyl-5H-pyridazino[3,4-d]-1,3-oxazin-7-} yl)propanoic acid (13)

To a solution of compound 5 ( $1 \mathrm{~g}, 0.0034$ mole) in dimethyl formamide $(10 \mathrm{ml})$ succinic anhydride $(0.34 \mathrm{~g}, 0.0034 \mathrm{~mole})$ was added. The reaction mixture was refluxed for $10 \mathrm{~h}$. After cooling the reaction mixture was poured into ice water and the precipitate was filtered, dried and washed with water. After dryness the product was recrystallized from ethanol. White crystals, yield $68.75 \%, \mathrm{mp} 218$ $220^{\circ} \mathrm{C}$, IR $\left(\mathrm{KBr}, \mathrm{cm}^{-1}\right): 3438(\mathrm{OH}), 1641(\mathrm{C}=\mathrm{O}$ cyclic $), 1707(\mathrm{C}=\mathrm{O}$ acid $), 1555$ $(\mathrm{C}=\mathrm{N}), \mathrm{MS} \mathrm{m} / \mathrm{z}(\%): 374\left[\mathrm{M}^{+}+1\right](13.7), 328\left[\mathrm{M}^{+}-\mathrm{COOH}\right]\left(100, \mathrm{~F}_{1}\right), 300\left[\mathrm{~F}_{1}-\right.$ $\left.\mathrm{C}_{2} \mathrm{H}_{4}\right]\left(6.09, \mathrm{~F}_{2}\right), 256\left[\mathrm{~F}_{2}-\mathrm{CO}_{2}\right]\left(0.26, \mathrm{~F}_{3}\right), 179\left[\mathrm{~F}_{3}-\mathrm{Ph}\right](3.36)$.

\section{Results and discussion}

This paper is devoted to a discussion of preparation of oxazine derivatives which are useful intermediates for the preparation of heterocyclic compounds. The pyridazine derivatives $\mathbf{4}$ and $\mathbf{5}$ depicted in (Scheme 1) were obtained by the reaction of pyridazinechloro-ester $\mathbf{1}$ - prepared according to reported method [11]- with sodium azide in ethanol afforded the azido- ester 2. Ethyl-3-azido5,6-diphenylpyridazine-4- carboxylate 2 was confirmed on the basis of analytical and spectral data. Thus, the IR spectrum showed an absorption band at $1734 \mathrm{~cm}^{-1}$ for the ester carbonyl group and an absorption band at $2338 \mathrm{~cm}^{-1}$ for the azido group. Moreover, the ${ }^{1} \mathrm{H}-\mathrm{NMR}$ spectrum revealed the presence of $3 \mathrm{H}$ triplet at $\delta$ 0.9 corresponding to the ester methyl protons, $2 \mathrm{H}$ quartet at $\delta 4.13-4.227$ for the methylene protons and $10 \mathrm{H}$ multiplet at $\delta$ 7.18-7.36 for the phenyl protons (2Ph).

The reaction of azido-ester $\mathbf{2}$ with triphenylphosphine in benzene provided triphenylphosphnium product 3. Ethyl 5,6-diphenyl-3((triphenylphosphoranylidene)amino)pyridazine-4- carboxylate $\mathbf{3}$ was assigned on the basis of analytical and spectral data. Thus, the IR spectrum of the reaction product showed an absorption band at for the ester carbonyl group at $1728 \mathrm{~cm}^{-1}$. Moreover, the ${ }^{1} \mathrm{H}-\mathrm{NMR}$ spectrum revealed the presence of $3 \mathrm{H}$ triplet at $\delta 0.928$ - 
1.088 corresponding to the ester methyl protons, $2 \mathrm{H}$ quartet at $\delta 4.129-4.184$ for the methylene protons and $25 \mathrm{H}$ multiplet at $\delta 7.108-7.866$ for the phenyl protons (5 Ph).

Refluxing of triphenylphosphnium product 3 in acetic acid $80 \%$ led to the formation of the amino-ester product 4 in good yield. Ethyl-3-amino-5,6diphenylpyridazine-4- carboxylate 4 was confirmed on the basis of analytical and spectral data. Its infrared spectrum showed the presence of $\mathrm{NH}_{2}$ group at $3476,3272 \mathrm{~cm}^{-1}$ and $\mathrm{C}=\mathrm{O}$ group at $1708 \mathrm{~cm}^{-1}$ and the ${ }^{1} \mathrm{H}-\mathrm{NMR}$ spectrum showed the presence of signals at $\delta 7.049-7.298(\mathrm{~m}, 10 \mathrm{H}, 2 \mathrm{Ph}), \delta 6.715\left(\mathrm{~s}, 2 \mathrm{H}, \mathrm{NH}_{2}\right), \delta$ 3.947-4.018 (q, 2H, $\left.\mathrm{CH}_{2}\right)$ and $\delta$ 0.793-0.840 ( t, 3H, $\left.\mathrm{CH}_{3}\right)$.

Hydrolysis of ester group of compound 4 with ethanolic sodium hydroxide gave rise to the pyridazinamino-acid product 5. 3-Amino-5,6-diphenylpyridazine-4carboxylic acid 5 was confirmed on the basis of analytical and spectral data. Thus the IR spectrum showed an absorption band at $1658 \mathrm{~cm}^{-1}$ for the carbonyl group and an absorption band at $3352,3270 \mathrm{~cm}^{-1}$ for the $\mathrm{NH}_{2}$ group, two broad bands between $2495-1984 \mathrm{~cm}^{-1}$ and strong band at $1658 \mathrm{~cm}^{-1}$ for $\mathrm{NH}^{+}, \mathrm{COO}^{-1}$<smiles>Nc1nnc(-c2ccccc2)c(-c2ccccc2)c1C(=O)O</smiles><smiles>C#Cc1n[nH+]c(N)c(C(=O)[O-])c1-c1ccccc1</smiles>

Moreover, the ${ }^{1} \mathrm{H}-\mathrm{NMR}$ spectrum revealed the presence of $10 \mathrm{H}$ multiplet at $\delta$ 7.188-7.368 for the phenyl protons and 2H singlet at $\delta 6.9$ for the $\mathrm{NH}_{2}$ group, no signal for $\mathrm{OH}$ group as a result of presence of amino acid as zwitter ion. 


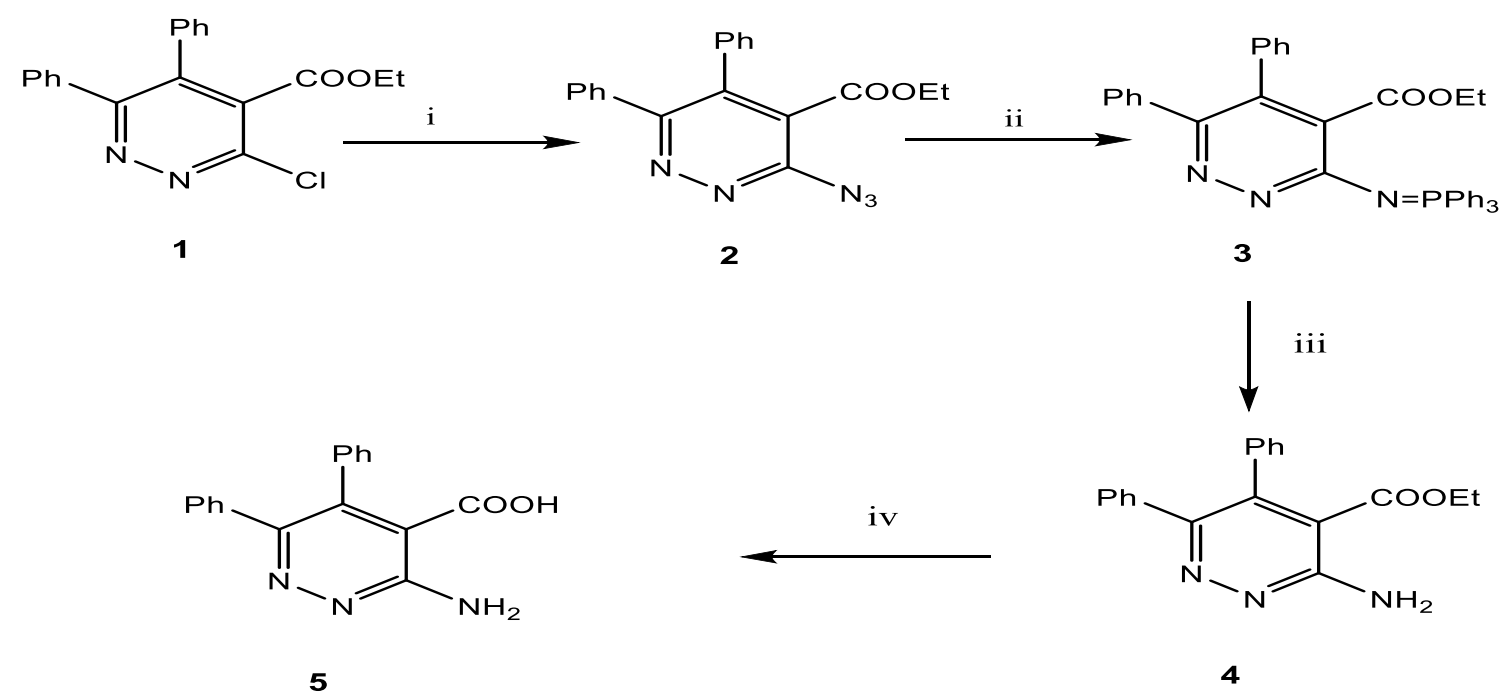

Scheme 1 Synthesis of derivatives 4, 5. Reagents and conditions $i \mathrm{NaN}_{3} / \mathrm{EtOH}$ ii $\mathrm{PPh}_{3}$, $\mathrm{C}_{6} \mathrm{H}_{6}$; iii $\mathrm{AcOH} 80 \%$; iv NaOH/EtOH

The pyridazinoxazine derivatives as the target compounds depicted in (Scheme 3 ). The precursor 7-methyl-3,4-diphenyl-5H-pyridazino[3,4-d][1,3]oxazin-5-one 6 was prepared by heating pyridazinamino-acid 5 in acetic anhydride under reflux. The infrared spectrum of the oxazine derivative $\mathbf{6}$ revealed presence of carbonyl group band at $1695 \mathrm{~cm}^{-1}$ and no absorption revealed to either $\mathrm{NH}$ group or acid carbonyl group. The ${ }^{1} \mathrm{H}-\mathrm{NMR}$ showed the presence of $10 \mathrm{H}$ multiplet at $\delta$ 7.206-7.376 due to the aromatic phenyl groups and 3H singlet at $\delta$ 2.493-2.505 due to the methyl group. The mass spectrum could be accounted as follow: it gives the molecular ion +1 at $\mathrm{m} / \mathrm{z} 316$, the molecular ion could lose $\mathrm{N}=\mathrm{C}-\mathrm{Me}$ to give the ion at $\mathrm{m} / \mathrm{z} 274$, which in turn lose $\mathrm{CO}_{2}$ to give the ion at $\mathrm{m} / \mathrm{z} 230$, then lose $\mathrm{Ph}$ radical to give an ion at $\mathrm{m} / \mathrm{z} 153$.

Pyridazinoxazine derivative $\mathbf{6}$ can also be prepared by, when a solution of this amino-ester 4 in glacial acetic acid containing a small excess of sodium acetate was heated with acetic anhydride under reflux, oxazine derivative $\mathbf{6}$ is obtained, it was identical (m.p,mixed m.p, IR) with that prepared from compound $\mathbf{5}$. (Scheme 2) 

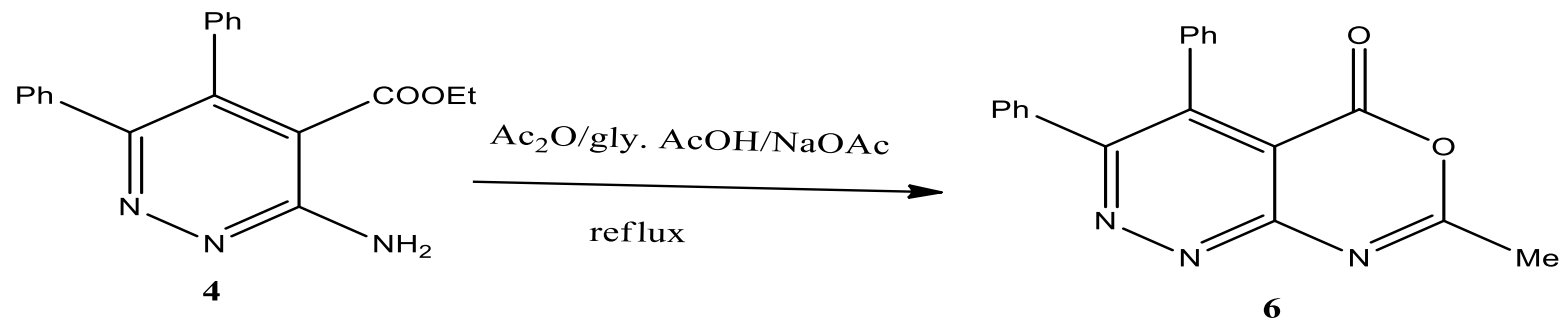

Scheme 2

Benzoylation of the solution of amino-acid $\mathbf{5}$ in pyridine with benzoyl chloride at r.t gave rise to N-benzoylamino-acid 7. However, when this reaction mixture is refluxed for a long time, pyridazinoxazine derivative $\mathbf{8}$ is formed in good yield.

3-Benzamido- 5,6-diphenylpyridazine-4- carboxylic acid 7 was assigned on the basis of analytical and spectral data. Thus, the IR spectrum of the reaction product showed an absorption band for the carbonyl group at $1685 \mathrm{~cm}^{-1}$, an absorption band at $3425 \mathrm{~cm}^{-1}$ for $\mathrm{OH}$ group and an absorption band at $3064 \mathrm{~cm}^{-1}$ for NH group. Moreover, the ${ }^{1} \mathrm{H}-\mathrm{NMR}$ spectrum revealed the presence of $1 \mathrm{H}$ singlet at $\delta 11.8$ for the $\mathrm{OH}$ group, $1 \mathrm{H}$ singlet at $\delta 11.4$ for the $\mathrm{NH}$ group and $15 \mathrm{H}$ multiplet at $\delta 7.151-8.063$ for the aromatic phenyl protons $(3 \mathrm{Ph})$. The mass spectrum could be accounted as follow: the molecular ion at $\mathrm{m} / \mathrm{z} 395$ underwent the following fragmentation, it could lose $\mathrm{COOH}$ to give the ion at $\mathrm{m} / \mathrm{z} 350$, which in turn could lose -NHCOPh to give the ion at $\mathrm{m} / \mathrm{z} 230$, then lose $\mathrm{Ph}$ radical to give the ion at $\mathrm{m} / \mathrm{z} 153$.

The infrared spectrum of the 3,4,7-triphenyl-5H-pyridazino[3,4-d]-1,3-oxazin-5one 8 showed the presence of carbonyl group band at $1769 \mathrm{~cm}^{-1}$ and no absorption revealed to either $\mathrm{NH}$ group or acid carbonyl group. The ${ }^{1} \mathrm{H}-\mathrm{NMR}$ showed the presence of $15 \mathrm{H}$ multiplet at $\delta 7.149-8.313$ due to the aromatic phenyl group. The mass spectrum could be accounted as follow: the molecular ion at $\mathrm{m} / \mathrm{z} 377$ underwent the following fragmentation, it could lose $\mathrm{N}=\mathrm{CPh}$ to give the ion at $\mathrm{m} / \mathrm{z} 274$, then lose $\mathrm{CO}_{2}$ to give the ion at $\mathrm{m} / \mathrm{z} 230$ which could lose $\mathrm{Ph}$ to give the ion at $\mathrm{m} / \mathrm{z} 153$.

Reaction of pyridazinamino-acid $\mathbf{5}$ with triethylorthoformate at refluxed temperature led to the formation of pyridazinoxazine derivative 9. The structure of 3,4-diphenyl-5H-pyridazino[3,4-d]-1,3-oxazin-5-one 9 was supported by its infrared and mass spectra. The infrared spectrum showed the presence of cyclic carbonyl group band at $1675 \mathrm{~cm}^{-1}$. The mass spectrum could be accounted as follow: it gives the molecular ion- 2 at $\mathrm{m} / \mathrm{z} 299$, the molecular 
ion could lose $\mathrm{N}=\mathrm{CH}$ to give the ion at $\mathrm{m} / \mathrm{z} 274$, then lose $\mathrm{CO}_{2}$ to give the ion at 230 which lose $\mathrm{Ph}$ radical to give the ion at $\mathrm{m} / \mathrm{z} 153$.

It was found that pyridazinamino-acid $\mathbf{5}$ on reaction with ethyl chloroformate in presence of pyridine yielded 7-ethoxy-3,4-diphenyl-5H-pyridazino[3,4-d]-1,3oxazin-5-one $\mathbf{1 0}$ in moderately yield. Identification of the structure $\mathbf{1 0}$ was achieved from its spectral data. The IR spectrum revealed band at $1695 \mathrm{~cm}^{-1}$ for the cyclic carbonyl group The mass spectrum could be accounted as follow : it give the molecular ion +1 at $\mathrm{m} / \mathrm{z} 346$, the molecular ion could lose $\mathrm{N}=\mathrm{COEt}$ to give the ion at $\mathrm{m} / \mathrm{z} 274$, then lose $\mathrm{CO}_{2}$ to give the ion at $\mathrm{m} / \mathrm{z} 230$, then lose $\mathrm{Ph}$ radical to give the ion at $\mathrm{m} / \mathrm{z} 153$.

Refluxing a solution of pyridazinamino-acid 5 with diethyl oxalate in dimethyl formamide, undergoes cyclization by an intramolecular nucleophilic addition with elimination of ethanol molecule produces pyridazinoxazine derivative $\mathbf{1 1}$. The isolated product was proven to be ethyl 5-oxo-3,4-diphenyl-5Hpyridazino[3,4-d]-1,3-oxazine-7-carboxylate 11 based on spectral data. The IR spectrum displays ester carbonyl group at $1663 \mathrm{~cm}^{-1}$, cyclic carbonyl group at $1627 \mathrm{~cm}^{-1}$. The mass spectrum could be accounted as follow: the molecular ion at $\mathrm{m} / \mathrm{z} 373$ underwent the following fragmentation, it could lose COOEt to give the ion at 300 , which in turn gives rise to the ion at $\mathrm{m} / \mathrm{z} 256$ by the lose of $\mathrm{CO}_{2}$, this could lose $\mathrm{Ph}$ to give the ion at $\mathrm{m} / \mathrm{z} 179$.

The pyridazinamino-acid 5 when reacted with phthalic anhydride in dimethyl formamide at refluxed temperature gave 2-( 5-oxo-3,4-diphenyl-5Hpyridazino[3,4-d]-1,3-oxazin-7-yl)benzoic acid 12. The structure of compound 12 is supported by its infrared and mass spectrum. The infrared spectrum revealed the presence of $\mathrm{OH}$ band at $3433 \mathrm{~cm}^{-1}$, acid carbonyl at $1784 \mathrm{~cm}^{-1}$ and cyclic carbonyl at $1725 \mathrm{~cm}^{-1}$. The mass spectrum gave a molecular ion at $\mathrm{m} / \mathrm{z}$ $421\left(\mathrm{M}^{+}\right)$in accord with the proposed structure. The molecular ion could lose

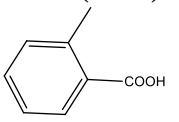

radical to give an ion at $\mathrm{m} / \mathrm{z} 300$, it also could lose $\mathrm{CO}_{2}$ radical to give the ion at $\mathrm{m} / \mathrm{z} 256$ which in turn loses phenyl radical to give the ion at m/z 179 . The pyridazinamino-acid 5 reacts with succinic anhydride in dimethyl formamide at reflux temperature to give 3-( 5-oxo-3,4-diphenyl-5Hpyridazino[3,4-d]-1,3-oxazin-7-yl)propanoic acid 13. The structure of compound 13 was supported by its infrared and mass spectrum. The IR spectrum revealed the presence of $\mathrm{OH}$ group at $3438 \mathrm{~cm}^{-1}$, acid carbonyl group at $1707 \mathrm{~cm}^{-1}$ and cyclic carbonyl group at $1641 \mathrm{~cm}^{-1}$. The mass spectrum could be accounted as follows : it give the molecular ion +1 at $\mathrm{m} / \mathrm{z} 374$, the molecular ion could lose $\mathrm{COOH}$ to give the ion at $\mathrm{m} / \mathrm{z} 328$, then lose $\mathrm{C}_{2} \mathrm{H}_{4}$ to give the ion at $\mathrm{m} / \mathrm{z} 300$ 
which lose $\mathrm{CO}_{2}$ to give the ion at $\mathrm{m} / \mathrm{z} 256$ which lose $\mathrm{Ph}$ radical to give the ion at $\mathrm{m} / \mathrm{z} 179$.<smiles>Nc1nnc(-c2ccccc2)c(-c2ccccc2)c1C(=O)O</smiles>

5<smiles>CCCCCCC</smiles><smiles>O=C(O)c1c(N=Cc2ccccc2)nnc(-c2ccccc2)c1-c1ccccc1</smiles>

7

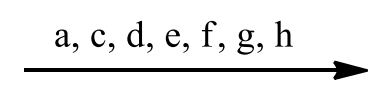<smiles>[R]c1nc2nnc(-c3ccccc3)c(-c3ccccc3)c2c(=O)o1</smiles>

$6,8,9,10,11,12,13$
6, $\mathrm{R}=-\mathrm{CH}_{3}$

9, $\mathrm{R}=-\mathrm{H}$

11, $\mathrm{R}=-\mathrm{COOEt}$
8, $\mathrm{R}=-\mathrm{Ph}$

10, $\mathrm{R}=-\mathrm{OEt}$

12, $\mathrm{R}=2(\mathrm{COOH}) \mathrm{C}_{6} \mathrm{H}_{4}$ -

13, $\mathrm{R}=-\mathrm{CH}_{2} \mathrm{CH}_{2} \mathrm{COOH}$

Scheme 3 Synthesis of derivatives $6,7,8,9,10,11,12,13$. Reagents and conditions $a$. $\mathrm{Ac}_{2} \mathrm{O}$; b. BzCl/Py./r.t ; c. BzCl/Py./reflux; d. CH(OEt) ${ }_{3}$; e. ClCOOEt/Py. ; f.DEO/DMF ; g. Phthalic anhydride/DMF ; h. Succinic anhydride/DMF

\section{Conclusion}

In summary we have developed a novel class of pyridazino[3,4-d][1,3]oxazin-5one derivatives which are useful intermediates for the preparation of heterocyclic compounds. It is known that 1,3-oxazin-6-ones which essentially are 5-aza-2pyrones, are attractive due to their high reactivity towards nucleophiles as aromatic amines producing new pyrimidopyridazines.

\section{References}

1. M. Asif, A. Singh, L. Ratnakar, J Pharm Res. (2011), 4(3): 664-667.

2. I. I. Mangalagiu, Curr Org Chem. (2011), 15(5):730-752. 
3. Deeb A, El-Eraky W, El-Awdan S, Mahgoub S (2014) Pyridazine and its related compounds, Part 34: hypoglycemic and hypolipidemic activity of some novel condensed pyridazine sulfonamides. Med Chem Res 23:34-41

4. Kandile NG, Mohamed MI, Zaky H, and Mohamed HM (2009) Novel pyridazine derivatives: synthesis and antimicrobial activity evaluation. Eur J Med Chem, 44 (5): 1989-1996.

5. Mangalagiu II (2011) Recent achievements in the chemistry of 1,2-diazines. Curr Org Chem, 15 (5):730-752.

6. Mantu D, Luca MC, Moldoveanu C, Zbancioc G and Mangalagiu II (2010) Synthesis and antituberculosis activity of some new pyridazine derivatives. Part II. Eur Med Chem, 45 (11): 5164-5168.

7. Drochioiu G, Sunel V, Oniscu C, Basu C and Murariu M (2007) The breakdown of plant biostructure followed by amino acids determination. Romanian Biotechnological Letters, 6 (2): 155-165.

8. Butnariu RM, Caprosu MD, Bejan V, Mangalagiu II, Ungureanu M, Poiata A, Tuchilus C, Florescu M (2007) Pyridazine and phthalazine derivatives with potential antimicrobial activity. J Hetrocycl Chem, 44 (5):1149-1152.

9. Han X, Hong YH, You Quan ZHU, Mao LIU Bim ZX, Fang Zhong HU, and Zheng YH (2010) Synthesis and herbicidal activities of novel 4- (3trifluoromethylphenyl)-2H-pyridazin-3-one derivatives. Science China Chemistry, 53 (1): 157-166.

Hansch C, Sammes PG, Taylor J B (1990) Comprehensive Medicinal Chemistry. Pergamon Press: Oxford, UK, Vol. 2, Chapter 7.1, pp 255-270.

10. Tucaliuc RB, Risca IM, Drochioiu G and Mangalagiu I (2008) Biological effect of some new pyridazine derivatives on wheat in germination experiments. Romanian Biotechnological Letters, 13 (4): 3837-3842.

11. Deeb A, Said S (1990) Studies on polyazaindenes synthesis of several new condensed pyridazine derivatives collect. Czech Chem Commun 55:27952799 


\section{تخليق وتفاعلات لبعض مشتقات البيريدازين}

تم تصميم سلسلة من مشتقات بيريدازينو [4،4-3،1، [d] أوكسازين-5-و ان وتجميعها من خلال طريقة متعددة الاستخدامات.عند تفاعل الكلورو استر 1 مع أزيد الصوديوم ينتج أزيدو أستر 2 التي تفاعلت مع دئن ثلاثي سفينيل فوسفين لإنتاج مركب 3؛ أمينو -إستر 4 تم تكوينه عند معالجة المركب 3 مع حامض الخليك 80\%. ثم تم تحلل هذا الأمينو استر 4 إلى الحمض الامينى 5. ويشمل النهج معالجة حمض لـ البيريدازينوامينو 5 مع أنهيدريد حض الخليك، كلوريد البنزويل، ثناثي إيثيل اورثوفورمات، كلوروفورمات الإيثيل، أوكسالات ثنائي إيثيل، أنهيدريد حمض الفتاليك وكذلك أنهيدريد حمض السكسينيك لانتاج مشتقات بيريدازينو أوكسازين 6 و 8 و 9 و 10 و 11 و 12 و 13. وقد تأكدت المركبات المصنعة الجديدة من خلال الأشعة تحت الحمر اء، الطيف الكتلي و الرنين المعناطيسى. 